\title{
Type of prey influences biology and consumption rate of Orius insidiosus (Say) (Hemiptera, Anthocoridae)
}

\author{
Simone M. Mendes ${ }^{1}$ \\ Vanda H. P. Bueno ${ }^{1}$ \\ Valdirene M. Argolo ${ }^{1}$ \\ Luis Cláudio P. Silveira ${ }^{1}$
}

\begin{abstract}
Generalist predators are capable of consuming different types of prey, and as each prey may have distinct nutritional values, each may have a distinct impact on the biology of the predator. Therefore, the aim of this study was to determine how the consumption of different prey influences certain biological characteristics and the predatory capacity of Orius insidiosus (Say). The investigation was performed in climatic chamber at $25 \pm 1{ }^{\circ} \mathrm{C}$, RH $70 \pm 10 \%$ and fotophase 12. Eggs of Anagasta kuehniella (Zeller), adults of Caliothrips phaseoli (Hood) and nymphs of Aphis gossypii Glover were used as prey and were provided daily ad libitum for all the mobile stages of the predator. The results showed that biological parameters of $O$. insidiosus are affected differently depending on the type of prey ingested. The development time of the nymphal stage was 13.1, 11.23 and 10.25 days for $O$. insidiosus feeding on eggs of A. kuehniella, nymphs of A. gossypii and adults of $C$. phaseoli, respectively. Longevity was five times larger for adults fed on eggs of A. kuehniella (56.25 days) compared to that of adults that preyed on nymphs of A. gossypii (11.44 days), and four times larger when the prey were adults of $C$. phaseoli (13.58 days). The consumption of eggs of A. kuehniella by predator females resulted in a shorter preoviposition period (3.2 days) and a longer oviposition period (44.4 days) when compared to the consumption of other types of prey. In addition, fecundity was increased with the consumption of eggs of A. kuehniella (195.25 eggs laid / female) when compared to feeding on the other prey, C. phaseoli (70.00 eggs laid / female) or A. gossypii (22.50 eggs laid / female). However, the consumption of aphids was larger (148.28 nymphs/ nymphal stage) than that of thrips (74.10 thrips / nymphal stage) or eggs of A. kuehniella (37.03 eggs /nymphal stage) for all of the nymphal stages of the predator. The results indicate that the eggs of A. kuehniella are the type of prey best suited for rearing this predator insect under laboratory conditions. Also fecundity was better with this prey even though the predator consumed during its nymphal stage a lesser quantity of eggs compared to the other prey.
\end{abstract}

KEYWORDs. Fecundity; longevity; predation; predatory capacity; prey

\section{INTRODUCTION}

The development and reproduction of insects correlate directly with the quantity and quality of the food they consume, and the ingestion of this food depends on its availability, acceptance, digestion and assimilation, in addition to being able to furnish all the nutrients required to produce energy and support increase in biomass (GARCIA 1991).

A generalist predator insect is capable of attacking diverse species of prey during its lifetime (EUBANKS \& DENNO 2000), thus being able to alter different characteristics of its biology depending on the species of prey consumed. According to LATTIN (2000), the insidiosus flower bug, Orius insidiosus (Say 1832), is a predator insect that feeds on small arthropods such as thrips, mites, aphids and eggs of Lepidoptera. These prey are found in various habitats, and $O$. insidiosus is thus capable of feeding as much on them as on pollen of plants.

This predator has been widely studied due to its value as an agent used in the biological control of mites and thrips in glasshouse conditions in Europe. However, according to LATTIN (1999; 2000), little is known about the species of anthocorids in the Southern Hemisphere, including their predatory capacity in regard to the different species of prey found in agricultural ecosystems south of the equator. Studies reported to date on these predator insects in Brazil according to BUENO (2000) are only modest and lack information such as the suitability of a prey species for rearing in the laboratory.

KIMAN \& YEARGAN (1985) studied the influence of different prey on the development time and fecundity of $O$. insidiosus and found that eggs of Heliothis virescens (Fabricius, 1781) provide for a larger fecundity in females. Lepidoptera eggs are considered by EuBANKs \& DENNo (2000) as high quality prey

1. Departamento de Entomologia, Universidade Federal de Lavras. Caixa Postal 37, 37200-000 Lavras - MG, Brazil.

E-mail: smmendes@ufla.br; vhpbueno@ufla.br 
for many generalist predators in contrast to aphids, which are considered low quality prey. The high nutritional quality of Lepidoptera eggs is related to the high nitrogen content they possess. Since nitrogen plays an important role in all metabolic processes and is an essential component in the make-up of the genetic code, it is thus a limiting factor among dietary components for insect growth and reproductive capacity (PARRA 1999).

BuENo (2000) proposed that nutritive and ecological information constitutes a potentially important element for studies that value the increase and optimization of the efficiency of predator insects as biological control agents. Thus, with the intention of contributing to the development of techniques for the rearing of $O$. insidiosus in the laboratory and to gain insight into the potential of this insect as a biological control agent, this work was undertaken to evaluate the biological characteristics and predatory capacity of this predatory insect when feeding on different prey, as eggs of Anagasta kuehniella (Zeller, 1879), Aphis gossypii Glover, 1877 and Caliothrips phaseoli (Hood, 1912).

\section{MATERIALAND METHODS}

The present study was conducted at the Laboratory of Biological Control at the Departamento de Entomologia, Universidade Federal de Lavras, in climatized chambers at 25 $\pm 1{ }^{\circ} \mathrm{C}, \mathrm{RH} 70 \pm 10 \%$ and fotophase 12 .

\section{Rearing/maintenance}

The rearing of the predator Orius insidiosus was carried out according to methods utilized by Mendes (2000) and for Anagasta kuehniella according to PARRA et al. (1985).
Aphis gossypii was reared on cotton plants (Gossypium hirsutum L.) which were kept in cages covered with a voil cloth.

Caliothrips phaseoli was reared and maintained on plants Canavalia ensiformis (L.) in acrylic cages, according to methods described by Lopes \& Alves (2000) for rearing Frankliniella occidentalis.

\section{Effect of different prey on the biological characteristics of}

\section{O. insidiosus}

Studies were conducted using three types of prey: nonhatched eggs of A. kuehniella, nymphs (up to $3^{\circ}$ ínstar) of $A$. gossypii and adults of $C$. phaseoli. A totally randomized design was utilized with 20 replications per treatment (type of prey) for the parameters studied in the nymphal stage, and with 8 replications per treatment for those studied in the adult stage.

The experimental unit was comprised of an individual predator kept in a Petri dish (5 $\mathrm{cm}$ in diameter), containing a small piece of moistened cotton and the prey utilized according to the treatment. In the treatment in which the prey was A. gossypii, a leaf about $14 \mathrm{~cm}^{2}$ in size from a cotton plant (G. hirsutum) was also added to prevent the aphids from dying due to dehydration or wasting, and that in which the prey was $C$. phaseoli, it was included a bean plant leaf (Phaseolus vulgaris L.), approximately $14 \mathrm{~cm}^{2}$ in size for reasons similar to those above.

The parameters examined were a) duration of the embryonic period, and of each instar and nymphal stage, b) periods of pre-oviposition and oviposition, c) fecundity and d) longevity. Fecundity was assessed by adding to the experimental unit an inflorescence of Bidens pilosa as a substrate for oviposition, from which the pollen was removed so as not to influence the nourishment of the adults.

Table I. Biological parameters of Orius insidiosus, regarding development and longevity with different types of prey.

Development time and longevity ( days)

\begin{tabular}{|c|c|c|c|c|}
\hline \multirow{2}{*}{$\begin{array}{l}\text { Biological } \\
\text { parameter }\end{array}$} & \multirow{2}{*}{$\mathrm{n}$} & \multicolumn{3}{|c|}{ Prey } \\
\hline & & A. kuehniella & A. gossypii & C. phaseoli \\
\hline Egg & 20 & $5.0 \pm 0.29 \mathrm{a}$ & $6.9 \pm 0.08 \mathrm{a}$ & $5.1 \pm 0.18 \mathrm{a}$ \\
\hline $1^{\circ}$ instar & 20 & $2.9 \pm 0.08 \mathrm{a}$ & $1.9 \pm 0.10 \mathrm{ab}$ & $1.9 \pm 0.05 \mathrm{a}$ \\
\hline $2^{\circ}$ instar & 20 & $2.1 \pm 0.06 \mathrm{a}$ & $1.9 \pm 1.00 \mathrm{ab}$ & $1.8 \pm 0.07 \mathrm{~b}$ \\
\hline $3^{\circ}$ instar & 20 & $2.0 \pm 0.05 \mathrm{a}$ & $2.1 \pm 0.17 \mathrm{a}$ & $2.3 \pm 0.13 b$ \\
\hline $4^{\mathrm{o}}$ instar & 20 & $2.1 \pm 0.07 \mathrm{ab}$ & $2.3 \pm 0.09 \mathrm{a}$ & $1.8 \pm 0.12 b$ \\
\hline $5^{\circ}$ instar & 20 & $3.9 \pm 0.11 \mathrm{a}$ & $3.3 \pm 0.17 b$ & $3.0 \pm 0.09 b$ \\
\hline Nymphal stage & 20 & $13.1 \pm 0.19 \mathrm{a}$ & $11.2 \pm 0.28 b$ & $10.2 \pm 0.12 c$ \\
\hline Longevity & 8 & $56.25 \pm 4.65 \mathrm{a}$ & $11.44 \pm 1.33 b$ & $13.6 \pm 1.86 \mathrm{~b}$ \\
\hline
\end{tabular}

Mean values in the same row followed by the same letter do not differ according to Tukey's test at $\mathrm{p}<0.01$ level of significance. 


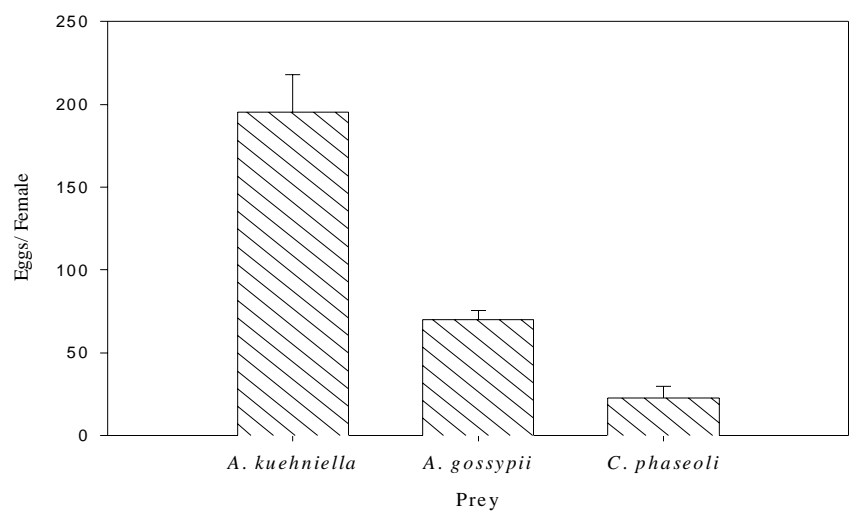

Fig. 1. Number of eggs laid per female of $O$. insidiosus fed on different prey.

\section{Consumption of prey}

The consumption of prey was evaluated for the nymphal stage of the predator, whereby each treatment was examined with 20 replications (eggs of A. kuehniella, nymphs (up to the $3^{\text {rd }}$ instar) of $A$. gossypii and adults of $C$. phaseoli). The experimental unit was similar to that in the preceding test. Observations were made daily, counting the number of prey consumed and replacing them with fresh ones retrieved from maintenance stocks. The consumption of prey was monitored for each instar stage and by the nymphal stage of the predator.

\section{Statistical analysis}

An analysis of variance was conducted for all parameters tested, and when the value of $\mathrm{F}$ was found to be significant, Tukey's test at $p<0.01$ level of significance, with the intention of detecting differences between mean values.

\section{RESULTS ANDDISCUSSION}

The predator $O$. insidiosus was capable of completing its nymphal stage by feeding on all the different prey offered, whether it be eggs of A. kuehniella, nymphs of A. gossypii or adults of $C$. phaseoli. Type of prey had a differential effect on development time of the different stages of the predator (Table
I).

The embryonic period was similar regardless of the different prey consumed by female, indicating that type of diet has no influence on this characteristic (Table I). The values obtained are similar to those reported by IsENHOUR \& Yeargan (1981), who demonstrated an embryonic period of 5.1 days for the same predator insect at $24 \pm 1^{\circ} \mathrm{C}$ and a 16 -h light period, when these insects were fed on eggs of Heliothis virescens. Nevertheless, ARGOLO (2000) observed that other factors could influence the duration of the embryonic period of this predator, such as the daily amount of light to which this insect is subjected.

It appeared that for all instar stages, there was a shorter time of development for $O$. insidiosus fed on $C$. phaseoli compared to insects allowed to feed on A. kuehniella eggs (Table I). This latter results was the same as its obtained by Tommasini \& Nicoli (1994), whereby predation on $F$. occidentalis by this same predator, yielded a shorter period of development when compared to those fed on A. kuehniella eggs. This provides evidence that in the laboratory rearing of this predator, thrips may be utilized when a shorter development time for $O$. insidiosus is desired.

For all instar stages of the predator nymph fed on eggs of A. kuehniella, there was a tendency towards an increased development time, as shown in the duration of the nymphal stage, which was larger than when nymphs were fed on Aphis gossypii or $C$. phaseoli (Table I). This result differs from those obtained by KimAn \& YEARGAN (1985), where $O$. insidiosus fed on eggs of $H$. virescens showed a shorter period of development (13.4 days) than when fed on thrips of Sericothrips variabilis (15.8 days).

The longevity of $O$. insidiosus fed on eggs of A. kuehniella (56.25 days), was about five times larger that when these flower bugs were fed on nymphs of $A$. gossypii (11.44 days) and four times larger than when fed on adults of $C$. phaseoli (13.58 days) (Table I). These results are similar to those obtained by Kiman \& YeARGAN (1985), where individuals fed on eggs of $H$. virescens demonstrated longevity three times larger than when fed on S. variabilis. RichARDS \& SCHMIDT (1996) found a longevity of 44 days for adults fed on eggs of A. kuehniella and pollen from corn, and Bush et al. (1993) demonstrated a lon-

Table II. Periods of pre-oviposition and oviposition for $O$. insidiosus fed on different prey.

\begin{tabular}{cccc}
\hline & \multicolumn{3}{c}{ Prey } \\
\cline { 2 - 4 } Period (days) & A. kuehniella & A. gossypii & C. phaseoli \\
\hline Pre-oviposition & $3.2 \pm 0.36 \mathrm{a}$ & $4.9 \pm 0.53 \mathrm{~b}$ & $6.3 \pm 0.47 \mathrm{~b}$ \\
Oviposition & $44.4 \pm 3.44 \mathrm{a}$ & $8.9 \pm 1.24 \mathrm{~b}$ & $13.2 \pm 1.80 \mathrm{~b}$ \\
\hline
\end{tabular}

Mean values in the same row followed by the same letter do not differ according to Tukey's test at $\mathrm{p}<0.01$ level of significance. 
gevity of about nine days for adults fed on A. gossypii. These results showed that Lepidoptera eggs provide for a larger longevity in this predator.

The type of prey offered to $O$. insidiosus had an influence on the pre-oviposition and oviposition periods (Table II). When these predators were fed on eggs of A. kuehniella, the preoviposition period was reduced by as much as half the time when compared to $O$. insidiosus fed on thrips (Table II). The oviposition period was about five times longer for individuals fed on eggs of $A$. kuehniella, compared to those fed on nymphs of A. gossypii (Table II).

The fecundity of females was therefore directly affected by the quality of their diet. Females fed on eggs of A. kuehniella laid about nine times more eggs $(195.3 \pm 22.77 \mathrm{eggs})$ than those fed on A. gossypii $(20.0 \pm 5.50$ eggs $)$ and three times more eggs than those fed on $C$. phaseoli (70.0 \pm 7.48$)$ (Fig.1). High rates of egg laying by females fed on Lepidoptera eggs was also observed by Tommasini \& Nicoli (1993), who reported that females fed on eggs of A. kuehniella laid about 2.5 times more eggs than females that preyed on $F$. occidentalis, and by BusH et al. (1993) who found that females fed on eggs of $H$. virescens laid five times more eggs than those that consumed on $A$. gossypii.

The results obtained here for the different types of prey examined point to the nutritional superiority of Lepidoptera eggs as the prey of choice for development and reproduction of $O$. insidiosus. This is probably due to the high nitrogen content present in these eggs, which guarantees a more adequate diet for the development of this predator in laboratory. However, in nature, the diversified availability of prey and other factors, in addition to nutritional quality of food, can define the selection process of the predator insect.

\section{Consumption of prey}

The consumption of prey by $O$. insidiosus was influenced by the type of prey offered, whereby a difference was observed between all the instar stages for which the consumption of aphids was larger than of thrips or A. kuehniella eggs. When the total consumption for the nymph stage was examined, the consumption of aphids was four times larger than that of $A$. kuehniella eggs, and two times larger than that of thrips (Table III).

The difference in the consumption of prey may be related to the nutritional quality of each. Based on a study by EUBANKS \& DENNo (2000), Lepidoptera eggs are prey of high quality for many generalist predators, while aphids are relatively of low nutritional quality. Therefore, the greater consumption of aphids by $O$. insidiosus may have occurred as function of the low nutritional quality of this prey. The predator attempts to fulfill the nutritional gap caused by the low quality of the prey by increasing its consumption; however, larger consumption is not reflected in the fecundity or longevity of the insect.

Conversely, EuBAnKs \& DENNO (2000) reported that mobility of the prey could also be an important factor in the selection of prey by generalist predators, and RosENHEIN et al. (1993) suggested that heteropteran predators attack and consume more often moving prey. This indicates that besides the nutritional quality of the prey, the movability of A. gossypii and $C$. phaseoli could be another factor that can account for the larger consumption of these prey by $O$. insidiosus, when compared to non-moving eggs.

All the prey tested may be considered adequate for the development $O$. insidiosus, and thus the predator is capable of completing its whole life cycle and reproducing having fed on these preys. Nevertheless, the results obtained in the present study point to the selection of $A$. kuehniella eggs as the prey most adequate for the rearing of this predator insect under laboratory conditions.

Table III. Consumption of different prey by Orius insidiosus in the nymphal stage.

\begin{tabular}{|c|c|c|c|c|}
\hline \multirow{3}{*}{$\begin{array}{c}\text { Stage / Phase of } \\
\text { Development }\end{array}$} & \multicolumn{4}{|c|}{ Consumption of prey } \\
\hline & \multirow{2}{*}{$\mathrm{n}$} & \multicolumn{3}{|c|}{ Prey } \\
\hline & & A. kuehniella & A. gossypii & C. phaseoli \\
\hline $1^{\circ}$ instar & 20 & $4.3 \pm 0.36 b$ & $13.1 \pm 0.91 \mathrm{a}$ & $6.3 \pm 0.54 b$ \\
\hline $2^{\circ}$ instar & 20 & $4.9 \pm 0.39 c$ & $19.60 \pm 1.22 \mathrm{a}$ & $9.1 \pm 0.72 b$ \\
\hline $3^{\circ}$ instar & 20 & $6.7 \pm 0.36 c$ & $23.0 \pm 1.30 \mathrm{a}$ & $11.1 \pm 1.17 b$ \\
\hline $4^{\circ}$ instar & 20 & $7.4 \pm 0.64 c$ & $36.0 \pm 2.65 \mathrm{a}$ & $16.2 \pm 1.21 b$ \\
\hline $5^{\circ}$ instar & 20 & $14.0 \pm 0.76 \mathrm{c}$ & $29.0 \pm 1.56 \mathrm{~b}$ & $63.0 \pm 3.19 \mathrm{a}$ \\
\hline Nymphal phase & 20 & $37.1 \pm 1.18 \mathrm{c}$ & $74.1 \pm 1.41 b$ & $148.3 \pm 5.6 \mathrm{a}$ \\
\hline
\end{tabular}

Mean values in the same row followed by the same letter do not differ according to Tukey's test at $\mathrm{p}<0.01$ level of significance. 
Acknowledgements. We thank Dr. M. G. Tommasini for identification of $O$. Insidiosus and Dr. R. Monteiro for identification of Caliothrips phaseoli. This study was made possible by fellowship grants received from CAPES and CNPq and additional financial support from FAPEMIG.

\section{REFERENCES}

Argolo, V. M. 2000. Influência de diferentes fotoperíodos no desenvolvimento e reprodução de Orius insidiosus (Say, 1832) (Heteroptera: Anthocoridae) Dissertação de Mestrado, Universidade Federal de Lavras, Lavras, 49p.

Bueno, V. H. P. 2000. Desenvolvimento e multiplicação de percevejos predadores do gênero Orius Wolff, p.69-90. In V. H. P. Bueno (ed.). Controle biológico de pragas: Produção massal e controle de qualidade. Lavras, Universidade Federal Lavras, 207p.

Bush, L.; T. J. KRING \& J. R. RuBSERSON. 1993. Suitability of greenbugs, cotton aphids, and Heliothis virescens eggs for the development and reproduction of Orius insidiosus. Entomologia Experimentalis et Applicatta 67:217-222

Eubanks, M. D. \& R. F. Denno. 2000. Health food versus fast food: the effects of prey quality and mobility on prey selection by a generalist predator and indirect interactions among prey species. Ecological Entomology 25: 140-146

GARCIA, M. A. 1991. Ecologia nutricional de parasitóides e predadores terrestres, p.289-311. In A. R. PANIZZI \& J.R.P. PARRA. (eds.), Ecologia nutricional de insetos e suas implicações no manejo de pragas. São Paulo, Manole, 359p.

Isenhour, D. J. \& K. V. Yeargan. 1981. Effect of temperature on the development of Orius insidiosus, with note on laboratory rearing. Annals of the Entomological Society of America 74:114-116.

Lattin, J. D. 1999. Bionomics of the Anthocoridae. Annual Review of Entomology 44: 207-231.
Lattin, J. D. 2000. Economic importance of minute pirate bugs (Anthocoridae), p. 607-637. In C. W. S. SCHOEFER \& A. R. PANIZZI (eds.). Heteroptera of Economic Importance. Florida, CRC Press, 828p.

Lopes, R. B. \& S. B Alves. 2000. Criação e observações preliminares da biologia de Frankliniella occidentalis (Pergrande) (Thysanoptera: Thripidae) em feijão-de-porco Canavalia ensiformis (L.) Anais da Sociedade Entomológica do Brasil 29(1):39-47

Kiman, Z. B. \& K. V. Yeargan. 1985. Development and reproduction of the predator Orius insidiosus (Hemiptera: Anthocoridae) reared on diets selected plant material and arthropod prey. Annals of the Entomological Society of America 78: 464-467,

Mendes, S. M. 2000. Desenvolvimento de Orius insidiosus (Say, 1832) (Hemiptera: Anthocoridae) alimentados com Aphis gossypii Glover, 1877 (Hemiptera: Aphididae) e Caliothrips phaseoli (Hood, 1912) (Thysanoptera: Thripidae) Dissertação de Mestrado. Universidade Federal de Lavras, Lavras, 79p.

Parra, J. R. P.; C. P. Stein; E. Bleicher; R. A. Zucchi \& S. Silveira Neto. 1985. Metodologia de criação de Anagasta kuehniella (Zeller, 1879) para pesquisas com Trichogramma spp. Piracicaba, FEALQ. $9 \mathrm{p}$.

PARRA, J. R. P. 1999 Técnicas para criação de insetos para programas de controle biológico, Piracicaba, ESALQ, FEALQ, 137P.

Richards, P. C. \& J. SchmidT. 1996. The effect of selected dietary supplements on survival and reproduction of Orius insidiosus (Say) (Hemiptera: Anthocoridae). Canadian Entomologist 128:171176.

Rosenhein, J. A.; L. R. Wilhoit \& C. A. Armer. 1993. Influence of intraguild predation among generalist insect predators on the suppression of an herbivore population. Oecologia 96: 439-449

Tommasini, M. \& G. Nicoli. 1993. Adult activity of four Orius species reared on two preys. Bulletin IOBC/WPRS 16: 281-184.

Tommasini, M. G. \& G. Nicoli. 1994. Pre-imaginal activity of four Orius species reared on two preys. Bulletin IOBC/WPRS 17: 237-241. 